\title{
Analysis of transcripts of heat shock protein genes in silkworm, Bombyx mori (Lepidoptera: Bombycidae)
}

\author{
Nalavadi CHANDRAKANTH ${ }^{2}$, Kangayam M. PONNUVEL ${ }^{1, *}$, Shunmugam M. MOORTHY ${ }^{2}$, \\ SIRIGINEEDI SASIBHUSHAN ${ }^{1}$ and VANKADARA SIVAPRASAD ${ }^{2}$ \\ ${ }^{1}$ Genomics Laboratory, Seribiotech Research Laboratory, Carmelaram Post, Kodathi, Bangalore 560 035, India; \\ e-mails:kmpvel@yahoo.com; sasibhushan.s@gmail.com \\ ${ }^{2}$ Molecular Biology Laboratory, Central Sericultural Research and Training Institute, Srirampura, Mysore 570008, India; \\ e-mails: chandra.nalavadi@gmail.com; moorthysm68@gmail.com; siva.nsso@gmail.com
}

Key words. Lepidoptera, Bombycidae, Bombyx mori, heat shock proteins, real time qPCR, thermotolerance

\begin{abstract}
Silkworm is a poikilothermic insect, whose growth and development is significantly affected by high temperatures. The current study aimed to identify bivoltine breeds tolerant of the high temperature conditions that occur in the tropics. Percentage pupation at high temperatures and heat shock responses of silkworms were used as measures of thermotolerance. Thermotolerance of 20 silkworm breeds was assessed by rearing them at $36^{\circ} \mathrm{C}$. Based on percentage pupation, three breeds, namely Nistari (multivoltine), SK4C (bivoltine) and CSR2 (bivoltine) were designated tolerant, moderately tolerant and susceptible, respectively. To understand the heat shock responses and the molecular mechanisms underlying thermotolerance, the tissue specific expression profiles of the nine heat shock protein $(H s p)$ genes were determined in the three breeds after a heat shock of $1 \mathrm{~h}$ at $36^{\circ} \mathrm{C}$ and a $2 \mathrm{~h}$ recovery period by performing real-time qPCR. The level of expression of $H s p$ genes was significantly increased in heat shocked tissues and gradually decreased during the recovery period. The greatest increase in the expression of $H s p$ genes was recorded in fat body followed by mid gut and silk gland. Of the three breeds, Nistari showed the highest expression of $H s p$ genes and SK4C a moderate expression relative to CSR2. The qPCR results showed that the transcript levels of $s H s p 20.4$ and 20.1, and $H s p 70$ were increased by $10.3,9.7$ and 2.3 times, respectively, in Nistari compared to CSR2. Similarly the expression of sHsp20.4 and 20.1, and Hsp70 were increased by 3.5, 2.3 and 1.5 times, respectively in SK4C compared to CSR2. The expression levels of Hsps during heat shock corresponded to the percentage pupation recorded for the three breeds at a high temperature. It is suggested that the Hsps and their levels of expression may play an important role in increasing the survival of silkworm larvae at high temperatures. This study identified SK4C as a bivoltine breed, which is highly tolerant of high temperature measured in terms of percentage pupation (of the bivoltine breeds) and higher levels of expression of $H s p$ genes compared to CSR2. The importance of SK4C as a thermotolerant bivoltine parent for breeding new bivoltine hybrids tolerant of high temperatures is discussed.
\end{abstract}

\section{INTRODUCTION}

Silkworm, Bombyx mori, is a domesticated insect recognized for its silk producing ability and as a model system for biological experiments. Continuous domestication has made silkworm sensitive to abiotic and biotic stresses, which can adversely affect the sericultural industry. Among the abiotic factors, temperature is an important determinant of growth and productivity as silkworms are poikilothermic insects (Benchamin \& Jolly, 1986). During summer, the temperature in tropical countries like India, where sericulture is important, goes beyond tolerable limits leading to poor growth of silkworm and silk yield. Generally, multivoltine (nondiapausing) silkworms are more tolerant of high temperatures than bivoltine (diapausing) strains, but produce inferior quality silk. On the other hand, bivoltine silkworms produce high quality silk but are less tolerant of high temperatures. Because of the hot climatic conditions prevailing in India, the success and spread of silkworm rearing is dependent on the introduction of $F_{1}$ hybrids between native multivoltine strains (high tempera- ture tolerance) as female parents and bivoltine strains (high quality silk) as male parents as they are hardy and can survive and reproduce in fluctuating environmental climatic conditions (Lakshmi et al., 2011). However, cocoon and silk yield, and quality of the silk yarn of such $\mathrm{F}_{1}$ hybrids is inferior to that of temperate bivoltine silkworm hybrids (Kumar et al., 2001; Singh \& Kumar, 2010). Because of these drawbacks, it is important to produce bivoltine breed because of their potential for increasing the production and quality of silk under the tropical conditions prevailing in India. However, attempts to use bivoltine silkworm breeds throughout the sericulture belt of India resulted in serious crop losses, especially in the hot and humid climatic conditions in the tropics (Kumar et al., 2001). Therefore, in India, the challenge is not only to develop stress and disease-resistant breeds but also breeds that produce a large quantity of high quality silk and thrive when the temperatures are high (Chavadi et al., 2006). Based on the survival of silkworm breeds at high temperatures, many Silkworm breeders' selected different bivoltine breeds as parents in order to develop hybrids and double hybrids (Shirota,

\footnotetext{
* Corresponding author.
} 
1992; Kumar et al., 2002, 2003, 2004, 2006; Rao et al., 2007; Krishna Rao et al., 2003). These breeds, however, were not widely adopted by the Indian sericulture industry as they did not perform well under field conditions (Singh \& Kumar, 2010). For this it is important to develop a bivoltine breed tolerant of the high temperature conditions in the tropics. The performance of any new silkworm strain in the field depends on molecular mechanisms in cells involved in what is referred to as the heat shock response (Howrelia et al., 2011).

The heat shock response is a universal phenomenon in which there is a rapid synthesis of a group of proteins known as heat shock proteins (Hsps) in response to thermal stress (Lindquist, 1986). Hsps serve as molecular chaperons that assist in the folding and translocation of newly synthesized proteins, as well as in coping with stress-induced denaturation of other proteins (Nover \& Scharf, 1997). Minimal temperature for induction of Hsps, involvement of different Hsps and their relative importance in stress tolerance differs from organism to organism (Parsell \& Lindquist, 1993). Cells that are pre-sensitized to sub-lethal temperatures show an increase in tolerance of high temperatures, a phenomena called inducible thermotolerance. There is sufficient evidence that inducible thermotolerance develops due to the accumulation of Hsps (Lozovskaya \& Evgen'ev, 1984; Lindquist, 1986; Morimoto et al., 1999; Margulis \& Guzhova, 2000). Based on their molecular weight, heat shock proteins are categorised as Hsp100, Hsp90, Hsp70, Hsp60 and low molecular weight proteins (Nover \& Scharf, 1997).

Hsp90 is abundant, highly conserved and makes up about $1-2 \%$ of the total protein in a normal eukaryotic cell (Lindquist \& Craig, 1988). They are constitutively expressed (absence of stress) and able to perform folding of non-native proteins (Welch et al., 1982), peptide translocation (Brugge et al., 1981) and signal transduction (Pandey et al., 2000) with the aid of several different co-chaperones (Pratt \& Toft, 2003). The Hsp90 gene of B. mori and Spodoptera frugiperda is characterized by a single long exon and is induced at high temperatures in S. frugiperda and ubiquitously expressed in several organs or tissues of $B$. mori (Landais et al., 2001).

Hsp 70 is characterized by a highly conserved N-terminal ATPase domain functionally coupled to a less conserved C-terminal peptide binding domain (Fink, 1999). There are two categories of $H s p 70$, the constitutive form heat shock cognate 70 (Hsc70), which is expressed under normal physiological conditions and inducible Hsp70, which is expressed under various stress conditions. The gene encoding $H s c 70$ has an intron, whereas Hsp 70 gene lacks an intron, which is heat inducible (Fink, 1999; Boutet et al., 2003). Hsc70 assists in folding of newly synthesized polypeptide chains and Hsp 70 assists in the refolding of denatured and misfolded proteins induced by stress (Morimoto, 1998). Members of the Hsp70 family cooperate with cofactors of the DnaJ/Hsp40 family in an ATP-dependent manner. In addition to ATP hydrolysis, Hsp 40 co-chaperone is also involved in directing the substrate proteins either to refold, or be degraded to Hsp70. Moreover, there is a highly significant correlation between Hsp70 expression and thermotolerance in Drosophila melanogaster (Welte et al., 1993; Feder, 1996), lizards, ants (Ul'masov et al., 1992; Gehring et al., 1995) and many other organisms (Feder \& Hofmann, 1999).

Small heat shock proteins (sHsps) are $15-30 \mathrm{kDa}$ in weight and occur as a homo-/heteromeric complex made of 2 to 40 subunits (Kappé et al., 2003). They consist of a conserved $\alpha$-crystallin domain of approximately $90-100$ amino acid residues and a conserved $\beta$-sheet in their secondary structure. Several subunits of sHSP form a large oligomer with the help of the $\beta$-sheet structures, sandwiched in a secondary structure of sHSP (Kim et al., 1998; Montfort et al., 2001). Under thermal stress this stable multimeric structure composed of monomers of sHSPs binds to the proteins and protects them from thermal denaturation through chaperone activity (Lee et al., 1995; Montfort et al., 2001; Nakamoto \& Vigh, 2007). Sakano et al. (2006) isolated and characterized six genes encoding sHsps in $B$. mori. They also found that all sHsps are up regulated after heat shock, except sHsp21.4.

One-dimensional gel electrophoresis revealed that in response to heat shock, $B$. mori produces three groups of heat shock proteins, including HSP82, HSP70 and sHSP (Lohmann \& Riddiford, 1992). The heat shock responses of the multivoltine silkworm breeds, C.Nichi and Pure Mysore, and the bivoltine breed, NB4D2, as indicated by the heat shock response of different tissues differs in terms of the presence of additional proteins (Joy \& Gopinathan, 1995). By exposing larvae to $40^{\circ} \mathrm{C}$ for $1 \mathrm{~h}$ and using O'Farrel's two-dimensional gel electrophoresis, Hsieh et al. (1995) identified 3 heat shock specific protein spots with molecular weights of about $70 \mathrm{kD}$ in the thermotolerant silkworm strain Nong (multivoltine), which are absent in the susceptible strain C-54 (bivoltine). Vasudha et al. (2006) report differential expression of heat shock proteins (Hsps) in different instars of bivoltine silkworm breeds viz., NB4D2, NP2, KSO1, CSR2 and CSR4, and confirm that the resistance to heat shock increases as larval development proceeds from first instar $>$ second instar $>$ third instar $>$ fourth instar $>$ fifth instar. Moghaddam et al. (2008) studied the proteome of heat tolerant (multivoltine) and heat susceptible (bivoltine) silkworms in response to heat shock using advanced protein analysis techniques, like 2D electrophoresis and mass spectrometry. This study demonstrate that the protein spot intensity of sHSPs is lower in multivoltine than in bivoltine breeds after heat shock treatment at $45^{\circ} \mathrm{C}$. Velu et al. (2008) report a higher expression of $H s p 70$ and $H s p 40$ genes at the tissue level after a heat shock of $1 \mathrm{~h}$ at $38^{\circ} \mathrm{C}$ and $42^{\circ} \mathrm{C}$ in the thermotolerant breed, Nistari (multivoltine) than the thermo susceptible breed, NB4D2 (bivoltine), using RT-PCR. The expression of $H s p 70$ and $H s p 40$ genes was highest in the fat body followed by the mid gut and silk gland. Li et al. (2005) analyzed the expression of the small heat shock protein gene BmHsp 19.9 in silkworms using RT-PCR and found varying levels of this protein in testis, ovary, silk gland and 
pupae. Li et al. (2014) performed digital gene expression analysis on the mid gut of the thermotolerant silkworm variety "932" (bivoltine) and thermosensitive variety "HY" (bivoltine) after exposure to high temperature and suggest that Hsps and the levels of their expression may be important in the resistance of silkworms to high temperature stress. Most of the studies on the heat shock response of $B$. mori involve using multivoltine breeds as they are thermotolerant and bivoltine breeds as they are thermo susceptible. Few reports (Vasudha et al., 2006; Li et al., 2014) are available on the heat shock response of bivoltine breeds as thermotolerants.

In the present study, 20 silkworm breeds were reared at a high temperature and based on the percentage that pupated, three breeds viz., Nistari, SK4C and CSR2, were designated tolerant, moderately tolerant and susceptible, respectively. Nistari is multivoltine and of tropical origin, a high percentage of which pupate at high temperatures ( $\mathrm{Li}$ et al., 2012) and synthesize heat stable esterase (Moorthy et al., 2007a). It is widely reared in North-East India. SK4C is a bivoltine breed, which is widely reared in North-East India. Its female parent is productive bivoltine breed "SK4" and male parent "Cambodge", which is tolerant of both high temperatures and high humidity. Cambodge is multivoltine and originates from Cambodia, has the dominant gene, Stu (for sturdiness or robustness), which accounts for its tolerance of high temperatures and humidity (Murakami \& Ohtsuki, 1989). SK4C is a near isogenic line of SK4. It was obtained by selecting larvae based on their surviving high temperature $\left(33^{\circ} \mathrm{C}\right)$ and humidity $(80-90 \%)$ and it has an esterase isozyme banding pattern similar to its multivoltine parent (Moorthy et al., 2007b). CSR2 is bivoltine and is widely reared in Southern India. It was bred from Japanese hybrids highly productive in favourable environ- mental conditions and as a consequence is not tolerant of high temperatures and humidity (Sreekumar et al., 2011). In the present study the tolerance of these three silkworm breeds was measured in terms of percentage pupation and expression of $H s p$ genes at high temperatures. The information generated provides better understanding of the relationship between Hsps expression and thermotolerance in the silkworm.

\section{MATERIAL AND METHODS}

\section{Rearing at a high temperature}

Twenty silkworm breeds, eighteen bivoltine and two multivoltine, were selected based on information on their thermotolerance. Larvae of these breeds were reared from hatching until they reached $2^{\text {nd }}$ day of $5^{\text {th }}$ instar at $25 \pm 2{ }^{\circ} \mathrm{C}$ and $75 \pm 3 \%$ relative humidity as suggested by Krishnaswami et al. (1978). There were 9 replications of this experiment with 100 larvae per replication. On the $3^{\text {rd }}$ day of $5^{\text {th }}$ instar, the larvae were exposed to $36^{\circ} \mathrm{C}$ in a SERICATRON (Environment chamber with temperature and humidity control) for $6 \mathrm{~h} /$ day until they started to spin a cocoon. The larvae were fed mulberry leaves twice a day and the mature larvae were mounted on plastic mountages for spinning cocoons. Cocoon harvesting was carried out on the $7^{\text {th }}$ day of spinning. Cocoons were deflossed and defective ones were rejected. The number of live and healthy cocoons was used to determine the percentage pupation. Based on this measurement, CSR2, Nistari and SK4C were categorized as susceptible, tolerant and moderately tolerant, respectively (Table 1).

\section{Heat shock and tissue collection}

On the $3^{\text {rd }}$ day of $5^{\text {th }}$ instar, CSR2, Nistari and SK4C larvae were separately exposed to $36^{\circ} \mathrm{C}$ for $1 \mathrm{~h}$ and then some of them were allowed to recover for $2 \mathrm{~h}$ at $25 \pm 2^{\circ} \mathrm{C}$. Larvae not subjected to a heat shock were used as controls. The treated (larvae exposed to a heat shock for $1 \mathrm{~h}$ at $\left.36^{\circ} \mathrm{C}\right)$, recovered $\left(2 \mathrm{~h}\right.$ at $25 \pm 2^{\circ} \mathrm{C}$ after heat shock) and control larvae were dissected separately, the silk gland, mid gut and fat body tissues of 5 larvae from each treat-

TABLE 1. Morphological characters and percentage pupation of twenty silkworm breeds.

\begin{tabular}{rccccc}
\hline Sl. No. & Breed & Larval marking & Cocoon shape & Cocoon colour & Percentage pupation (\%) \\
\hline 1 & ATR16 & Plain & Dumbbell & White & 19.22 \\
2 & ATR29 & Marked & Dumbbell & White & 40.44 \\
3 & BHR2 & Marked & Dumbbell & White & 43.89 \\
4 & BHR3 & Marked & Dumbbell & White & 59.67 \\
5 & B37 & Plain & Oval & White & 12.56 \\
6 & CSR2 & Plain & Oval & White & 12.22 \\
7 & CSR17 & Plain & Oval & White & 27.89 \\
8 & CSR46 & Plain & Oval & White & 40.67 \\
9 & CSR47 & Marked & Dumbbell & White & 28.33 \\
10 & CSR50 & Plain & Oval & White & 36.33 \\
11 & CSR51 & Marked & Dumbbell & White & 18.56 \\
12 & D6(P) & Marked & Dumbbell & White & 28.22 \\
13 & D6(P)N & Marked & Dumbbell & White & 44.40 \\
14 & NN6D & Plain & Oval & White & 44.22 \\
15 & S-38 & Plain & Oval & White & 22.67 \\
16 & SK3 & Plain & Oval & White & 32.44 \\
17 & SK4 & Marked & Dumbbell & White & 38.56 \\
18 & SK4C & Marked & Dumbbell & Yellow & 60.89 \\
19 & Nistari* & Marked & Spindle & Yellow & 85.11 \\
20 & Cambodge* & Plain & Spindle & & 84.00 \\
\hline
\end{tabular}

\footnotetext{
* multivoltine breeds.
} 
ment were collected and pooled to minimize variation, frozen in liquid nitrogen and stored at $-80^{\circ} \mathrm{C}$ until used.

\section{Total RNA extraction and cDNA preparation}

Total RNA was extracted from $100 \mathrm{mg}$ of silk gland, mid gut and fat body using TRIzol reagent (Invitrogen, USA), as per manufacturer's instructions. The frozen tissues of silk gland, mid gut and fat body were separately ground to a fine powder in liquid nitrogen with the immediate addition of TRIzol reagent $(1 \mathrm{ml})$. To assess the quantity and integrity of RNA, the total RNA was denatured in formaldehyde, formamide and electrophoresed on $2.0 \%$ agarose gels. The first strand cDNA was synthesized using the DNase treated RNA sample $(2 \mu \mathrm{g})$, and adding $1 \mu \mathrm{l}$ oligo $(\mathrm{dT})_{18}(0.01 \mathrm{mM})$ (Eurofin India Pvt Ltd, Bangalore) followed by incubation at $70^{\circ} \mathrm{C}$ for $3 \mathrm{~min}$. Finally, $1 \mathrm{X}$ reverse transcriptase buffer $(4 \mu \mathrm{l}), 10 \mathrm{mM}$ dNTP $(2 \mu \mathrm{l}), 5 \mathrm{mM}$ DTT $(2 \mu \mathrm{l})$ and M-MLV Superscript III reverse transcriptase (Invitrogen, USA) $(0.5 \mu \mathrm{l})$ were added to obtain a final volume of $20 \mu$. The reaction mixture was incubated at $42^{\circ} \mathrm{C}$ for $60 \mathrm{~min}$ and terminated by heating at $75^{\circ} \mathrm{C}$ for $10 \mathrm{~min}$ according to the manufacturer's protocol.

\section{cDNA quantification}

The expression of nine Hsp genes in different tissue/breed/ treated or recovery combinations was analyzed by performing qRT-PCR with reverse transcribed product and gene-specific primers. The total RNA isolated from heat shocked and recovered tissues were calibrated relative to the values recorded for the control larvae. The calibrator was included on each plate. The fluorescent ROX dye (Takara) was used as an internal control of pipetting errors and well-to-well differences. Each sample was tested in triplicate. One $\mu 1$ of first strand cDNA was used in a 20 $\mu \mathrm{l}$ reaction mixture using the specific primers designed for Real time PCR (qPCR). The primer details are listed in Table 2. The reactions were conducted on a STRATAGENE Mx 3005P real time PCR system. The relative expression levels of each gene at different times were normalized using the $\mathrm{Ct}$ values obtained for the $\beta$-actin amplifications run on the same plate. The mean value $\pm \mathrm{SD}$ was used for the analysis of relative levels of expression of genes for each tissue/breed/treatment using the $\Delta \Delta \mathrm{Ct}$ method. A non-template control (NTC) sample was also run to detect any

TABLE 2. Primer pairs used for quantitative RT-PCR.

\begin{tabular}{|c|c|c|}
\hline Gene & Accession No. & Primer pairs \\
\hline \multirow{2}{*}{ Hsp19.9 } & \multirow{2}{*}{ NM_001043519 } & TGTACGGCTGAATCTGTGGA \\
\hline & & TTGGATTGGTCCTTCACCTC \\
\hline \multirow{2}{*}{ Hsp20.1 } & \multirow{2}{*}{ NM_01043476 } & GCCAACGATGTCCAGAGATT \\
\hline & & CTGCCTCTCCTCGTGCTTAC \\
\hline \multirow{2}{*}{ Hsp20.4 } & \multirow{2}{*}{ AF315318 } & TTTTGGCCTTGCCTTAACAC \\
\hline & & TTCGCTCTGGTCCTTGATCT \\
\hline \multirow{2}{*}{ Hsp20.8 } & \multirow{2}{*}{ AF315317 } & CTAACCCCGAACGACATGCT \\
\hline & & GATGTACCCATCGGCAGTCT \\
\hline \multirow{2}{*}{ Hsp21.4 } & \multirow{2}{*}{ AB 195972} & CCGAAATGAGGAAGATGGAA \\
\hline & & GAATGAGCGGCGAGTTTAAG \\
\hline \multirow{2}{*}{ Hsp23.7 } & \multirow{2}{*}{ NM_01043477 } & GGACGAGCACGGATACATTT \\
\hline & & CCGGGCCAGTTTTAGTGATA \\
\hline \multirow{2}{*}{ Hsp40 } & \multirow{2}{*}{ AB206400 } & TCGGACGATGACATCAAGAA \\
\hline & & CCCGGGCGATATCTTCTAAT \\
\hline \multirow{2}{*}{ Hsp 70} & \multirow{2}{*}{ DQ311189 } & GAACACACTCGCTGCACATC \\
\hline & & GAGGAGTGCCCAAGATCGAC \\
\hline \multirow{2}{*}{ Hsp90 } & \multirow{2}{*}{ AB060275 } & TTCCCAGTTCATTGGCTACC \\
\hline & & TCTTGCGCTTCTTGTTTTCA \\
\hline
\end{tabular}

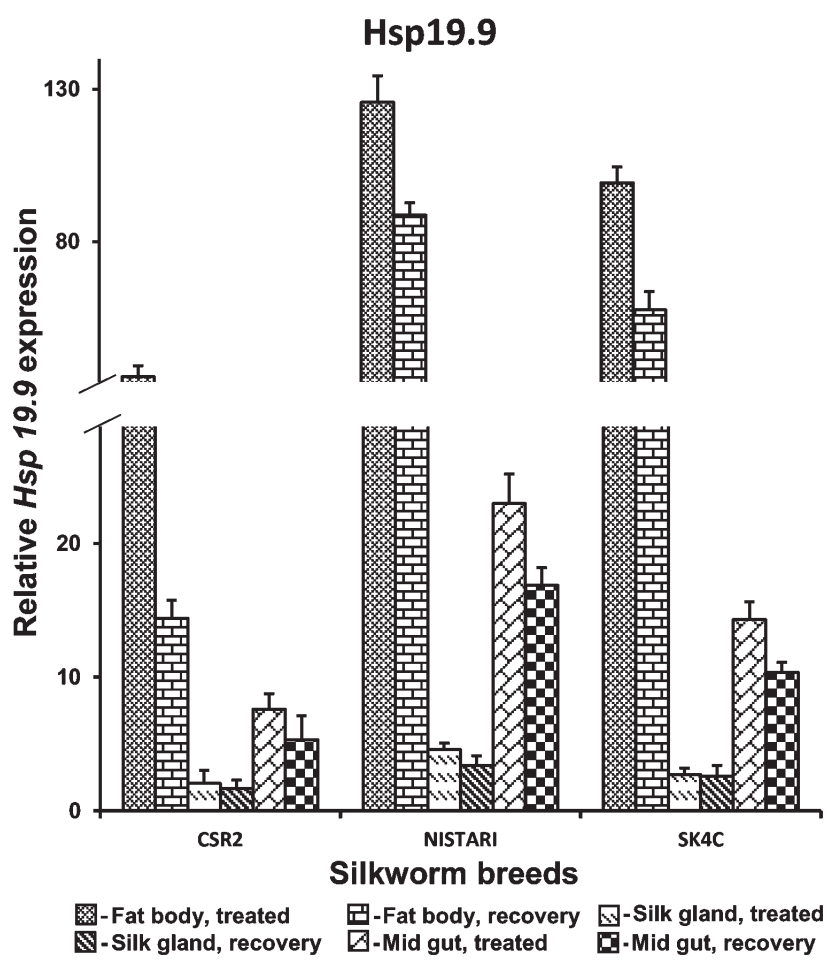

Fig. 1. The relative levels of expression of Hsp19.9 in different tissue/breed/treated or recovery combinations. This experiment was performed in triplicate and the quantity of Hsp19.9 mRNA normalized by using the transcript quantity of $\beta$-actin in non-heat shocked tissue at 0 -hour.

contamination. The two-way analysis of variance (ANOVA) was performed with SPSS software with breeds and tissues as factors for each $H s p$ gene.

\section{RESULTS}

\section{Selection of silkworm breeds}

Of the twenty silkworm breeds subjected to a heat shock Nistari was the most tolerant and CSR2 the least tolerant. In addition, among the bivoltine breeds SK4C survived best. The survival of the larvae of Nistari was 1.3 and 6.9 times greater than that of SK4C and CSR2, respectively. Similarly, 4.8 times more larvae of SK4C survived than of CSR2. Thus, CSR2 (12.22\%), Nistari (85.11\%) and SK4C $(60.89 \%)$ were categorized as susceptible, tolerant and moderately tolerant of heat shock, respectively. The morphological characters and percentage pupation of these silkworm breeds are presented in Table 1 .

\section{Expression of Hsps in tissues of the different breeds subjected to a heat shock}

The relative mRNA levels of nine $H s p$ genes were quantified using real time qPCR of the fat body, mid gut and silk gland tissues of 3 day old $5^{\text {th }}$ instar larvae of CSR2, Nistari and SK4C breeds after a heat shock of $1 \mathrm{~h}$ at $36^{\circ} \mathrm{C}$ followed by $2 \mathrm{~h}$ of recovery at $25 \pm 2^{\circ} \mathrm{C}$. Non-heat shock samples at $0 \mathrm{~h}$ with both genes of interest and $\beta$-actin genes were used to calibrate variation in RNA/cDNA extractions. The results indicate that the expression of the Hsp gene was not the same in all the tissues. It increased, however, after heat shock and decreased during the recovery period. The high- 
Hsp 20.1

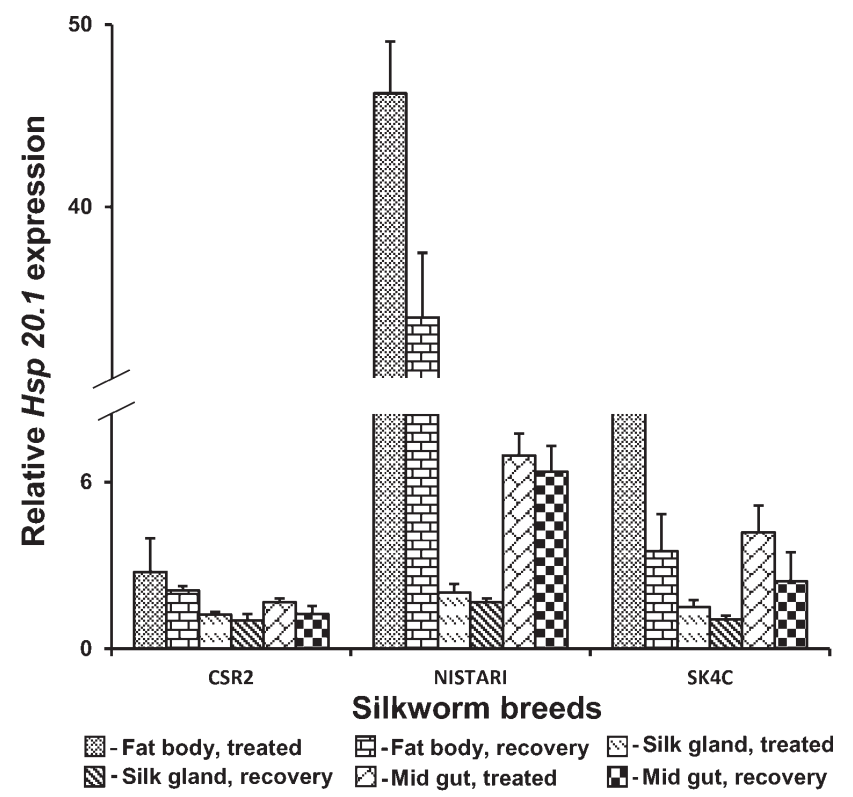

Fig. 2. The relative levels of expression of Hsp20.1 in different tissue/breed/treated or recovery combinations. This experiment was performed in triplicate and the quantity of Hsp20.1 mRNA normalized by using the transcript quantity of $\beta$-actin in non-heat shocked tissue at 0-hour.

est increase was recorded in the fat body followed by mid gut and silk gland of the three selected silkworm breeds.

The quantity of $H s p$ gene transcript in the different tissues after heat shock was in the order $s H s p 20.4>H s p 70>$ Hsp $40>$ sHsp $23.7>$ sHsp2O.8 > sHsp19.9>sHsp2O.1 >

\section{Hsp20.4}

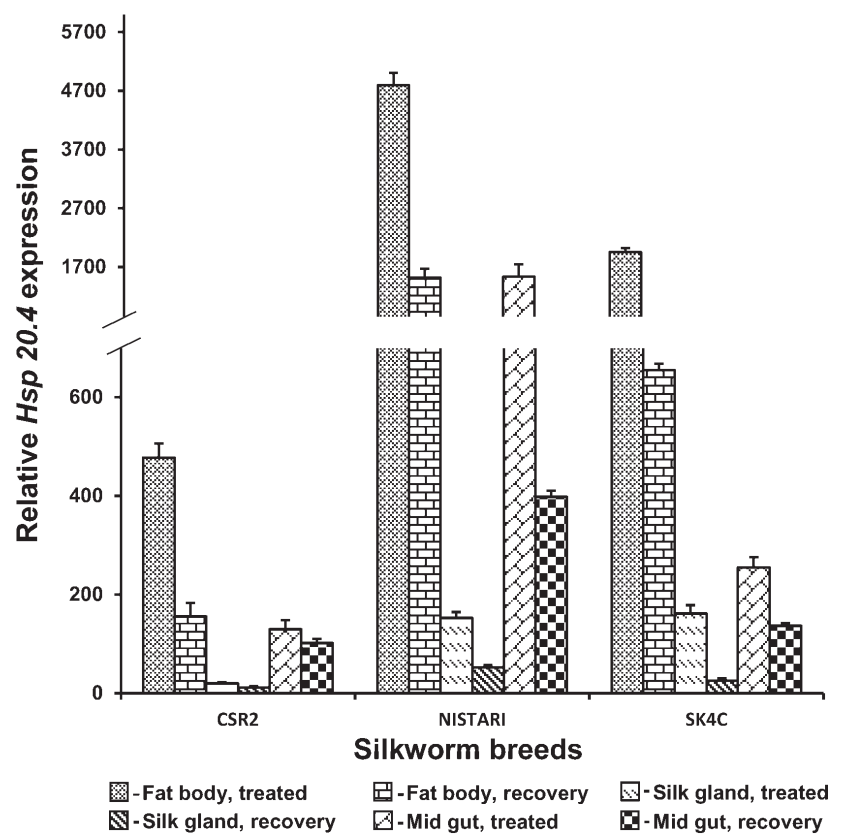

Fig. 3. The relative levels of expression of Hsp20.4 in different tissue/breed/treated or recovery combinations. This experiment was performed in triplicate and the quantity of Hsp20.4 mRNA normalized by using the transcript quantity of $\beta$-actin in non-heat shocked tissue at 0 -hour.

\section{Hsp20.8}

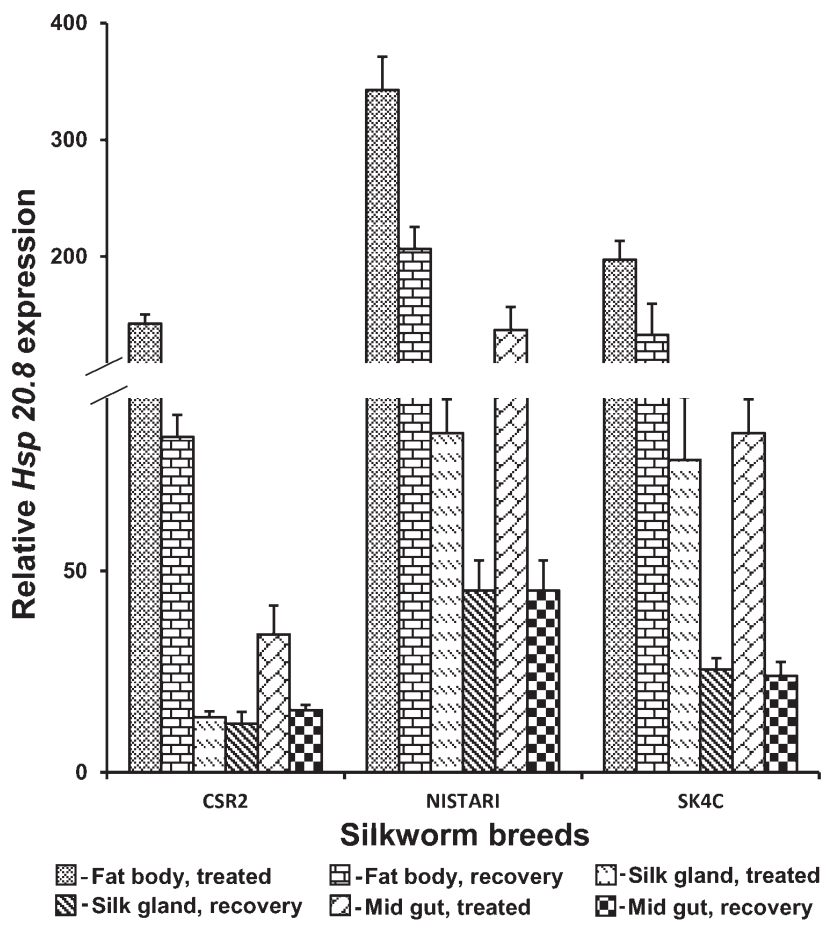

Fig. 4. The relative levels of expression of Hsp20.8 in different tissue/breed/treated or recovery combinations. This experiment was performed in triplicate and the quantity of Hsp20.8 mRNA normalized by using the transcript quantity of $\beta$-actin in non-heat shocked tissue at 0 -hour.

Hsp $90>$ sHsp21.4 (Figs 1-9). Even though the expression of Hsp in the different tissues was same, the level of expression differed greatly. For example, the level of expression of sHsp20.4 and Hsp70 in the mid gut was 10 times and 4.7 times greater than in the silk gland, and 0.32 and 0.85 times less than in the fat body in Nistari, respectively (Figs 3 and 8). Similar differences were recorded for the fat body, mid gut and silk gland tissues of the selected breeds with respect to each $H s p$ member indicating the expression of Hsp genes is tissue specific. Moreover, for the fat body

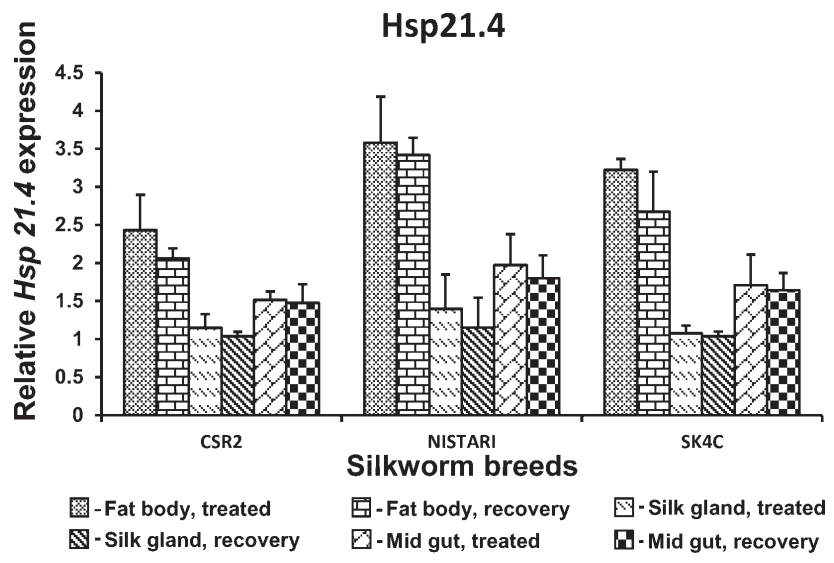

Fig. 5. The relative levels of expression of Hsp21.4 in different tissue/breed/treated or recovery combinations. This experiment was performed in triplicate and the quantity of $H s p 21.4$ mRNA normalized by using the transcript quantity of $\beta$-actin in non-heat shocked tissue at 0-hour. 
Hsp23.7

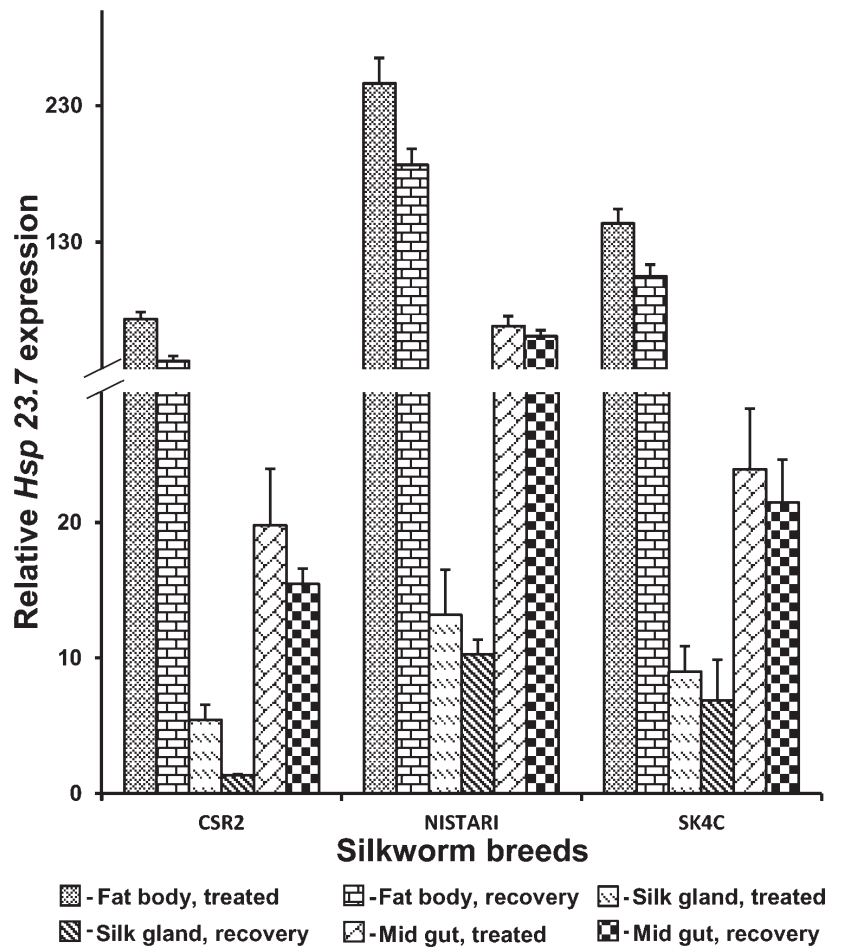

Fig. 6. The relative levels of expression of Hsp23.7 in different tissue/breed/treated or recovery combinations. This experiment was performed in triplicate and the quantity of $H s p 23.7$ mRNA normalized by using the transcript quantity of $\beta$-actin in non-heat shocked tissue at 0 -hour.

in Nistari the highest expressed gene $s H s p 20.4$ differed from lowest expressed gene $H s p 21.4$ by more than 1338 times. Similarly, for the fat body of SK4C sHsp20.4 was expressed 605 times more than Hsp21.4 (Fig. 5). These results indicate that the $H s p$ genes are differently expressed at the tissue level.

\section{Expression of $\boldsymbol{H}$ sps in larvae recovering from heat shock}

The expression of $H s p$ genes in the tissues of larvae recovering from heat shock was considerably less than in the tissue of larvae that have just experienced a heat shock. The profile of expression of $H s p$ in recovering larvae and those that have just experienced a heat shock was the same but the level of expression differed. The level of expression of $H s p s$ in the tissues of recovering larvae was highest in fat body followed by mid gut and silk gland. The genes that were expressed most in the fat body of larvae recovering from heat shock were $s H s p 20.4$ and $H s p 70$, which were expressed 9.7 and 2.7 times more, respectively, in Nistari than in CSR2. Similarly, sHsp 20.4 and $H s p 70$ were 4.2 and 1.4 times more expressed in the fat body of larvae recovering from heat shock of SK4C than CSR2 (Figs 3 and 8).

\section{Expression of $\mathrm{Hsps}$ in breeds of silkworm that are susceptible, tolerant and moderately tolerant to heat shock}

The expression of all nine Hsps in CSR2 (susceptible), Nistari (tolerant) and SK4C (moderately tolerant) were sig-
Hsp40

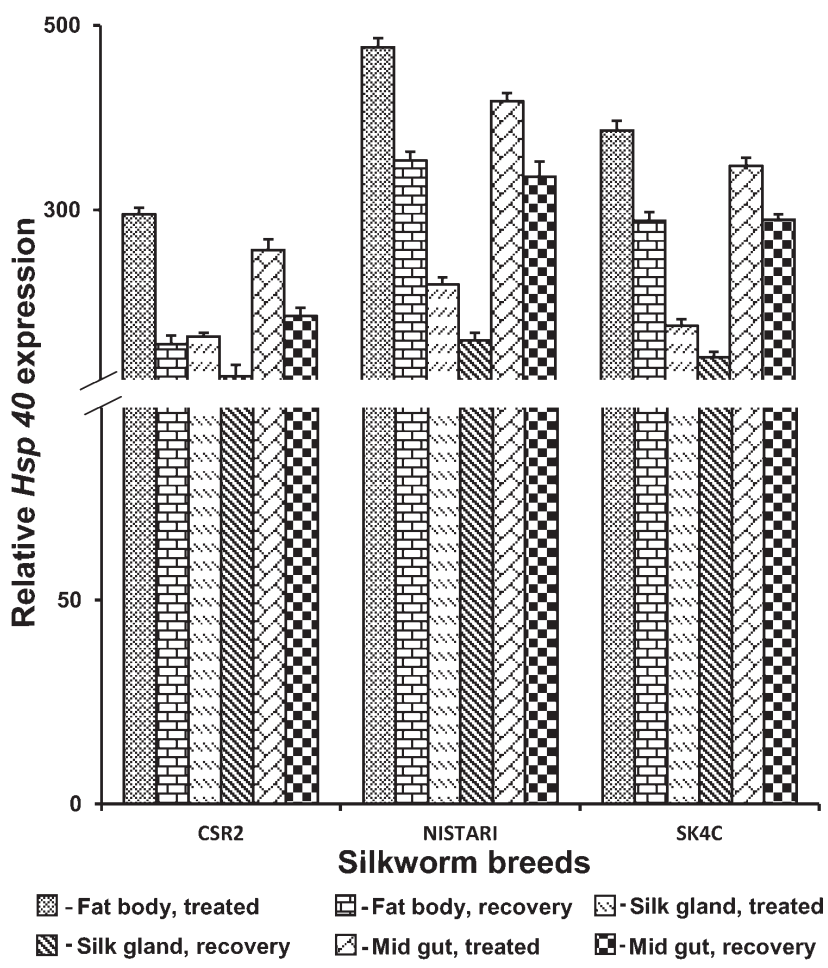

Fig. 7. The relative levels of expression of Hsp40 in different tissue/breed/treated or recovery combinations. This experiment was performed in triplicate and the quantity of $H s p 40$ mRNA normalized by using the transcript quantity of $\beta$-actin in non-heat shocked tissue at 0 -hour.

nificantly up-regulated. Generally, the expression of $H s p$ genes was high in Nistari and low in CSR2, with an intermediate level of expression in SK4C (Figs 1-9). The highly expressed $H s p$ genes viz., $s H s p 20.4$ and $H s p 70$, were 9.4 and 2.3 times, respectively, more highly expressed in Nistari than CSR2. Similarly, the expression of $s H s p 20.4$ and $H s p 70$ was 3.5 and 1.5 times, respectively, more highly expressed in SK4C than CSR2. However, the increase in the expression of other $H s p$ members was not less than 1.4 and 1.2 times in Nistari and SK4C, respectively, compared to CSR2. Two-way ANOVA with tissues and breeds as factors revealed significant differences $(P<0.05)$ in the expression of all the Hsp genes (except $H s p 90$ ) (Table 3).

\section{DISCUSSION AND CONCLUSIONS}

The objective of this study was to identify breeds of bivoltine silkworms that can be reared at the high temperatures prevailing in the tropics. The thermotolerance of different breeds of $B$. mori is measured by recording the percentage pupation of larva reared at a high temperature (Huang et al., 1979; He \& Oshiki, 1984). Therefore, 3 day old $5^{\text {th }}$ instar larvae of 20 silkworm breeds were exposed to $36^{\circ} \mathrm{C}$ for $6 \mathrm{~h}$ every day until they started to spin cocoons. Using a $6 \mathrm{~h}$ heat shock everyday was thought to best mimic the daily fluctuation in temperature experienced in the tropics. The thermotolerant ability of multi- and bivoltine silkworm breeds measured in terms of percentage pupation differed. The percentage pupation recorded for multivoltine breeds 


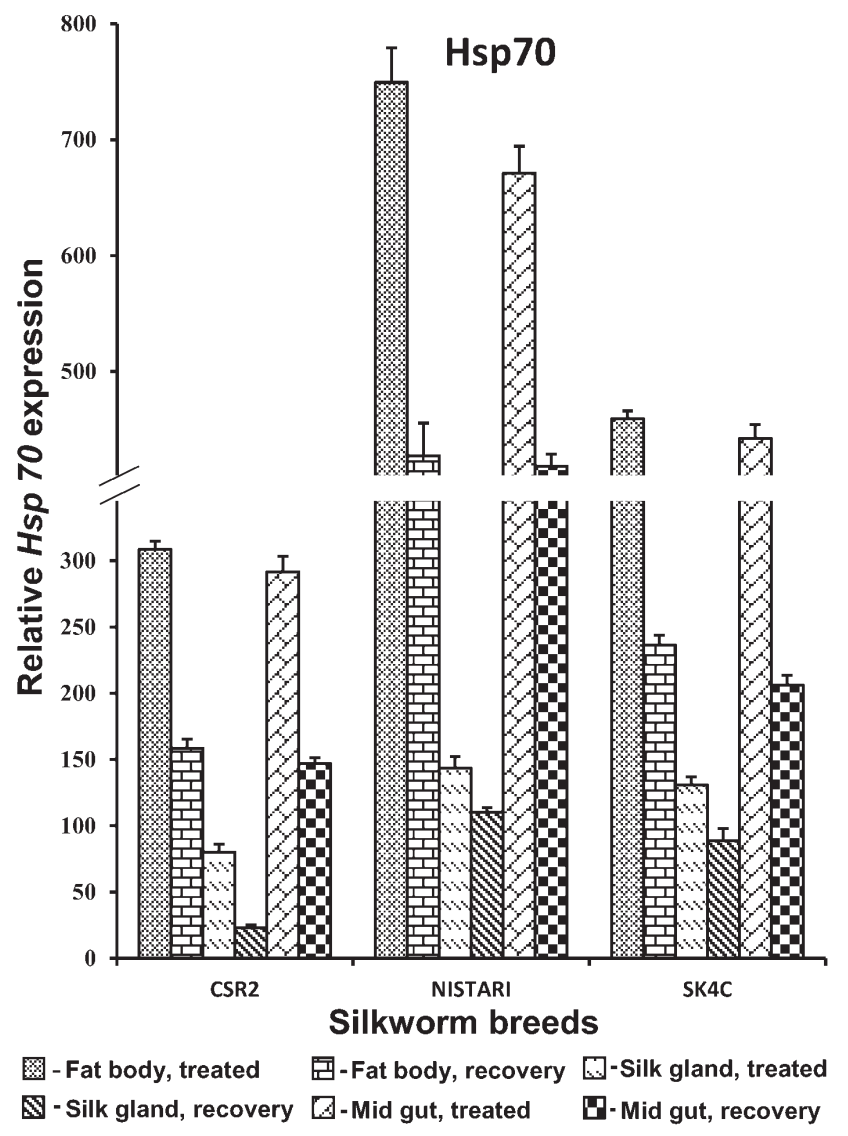

Fig. 8. The relative levels of expression of $H s p 70$ in different tissue/breed/treated or recovery combinations. This experiment was performed in triplicate and the quantity of $H s p 70 \mathrm{mRNA}$ normalized by using the transcript quantity of $\beta$-actin in non-heat shocked tissue at 0 -hour.

was higher than that recorded for bivoltine breeds. The percentage pupation of the bivoltine breeds varied markedly indicating it might be possible to select bivoltine breeds for better thermotolerance. For the 20 silkworm breeds tested, the highest percentage pupation was recorded for Nistari and the lowest for CSR2. These two breeds experience very different natural thermal regimes; Nistari is a multivoltine breed native to tropical areas whereas CSR2 is a bivoltine breed native to temperate areas, which provides a high cocoon yield but is very sensitive to high temperatures. Generally, multivoltine breeds are better able to survive a heat shock than bivoltine breeds (Hsieh et al., 1995; Joy \& Gopinathan, 1995). Koundinya et al. (2003) report that Nistari is the most tolerant of high temperatures of the 11 multivoltine breeds they tested. Based on percentage pupation, Srivastava et al. (2007) classified 15 multivoltine breeds as 6 tolerant, 5 moderately tolerant and 4 susceptible. Joy \& Gopinathan (1995) report high percentage survival for the multivoltine silkworm breeds, C.Nichi and Pure Mysore, and low percentage survival for the bivoltine breed, NB4D2, after a heat shock of $1 \mathrm{~h}$ or $2 \mathrm{~h}$ at $39^{\circ} \mathrm{C}$ or $41^{\circ} \mathrm{C}$. Similar results are reported by Hsieh et al. (1995) after a heat shock of $1 \mathrm{~h}$ at one of several high temperatures.

For the bivoltine breeds the highest percentage pupation of $60.89 \%$ was recorded for SK4C, which is 4.8 times

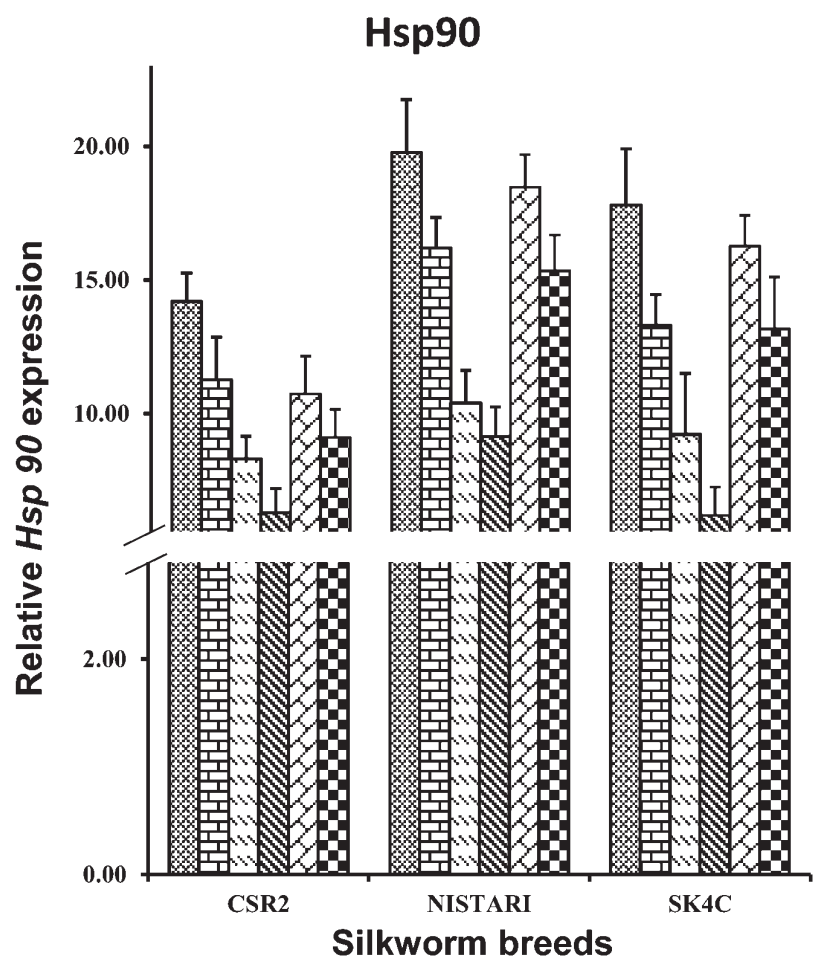

图-Fat body, treated $\square$-Fat body, recovery $\square$-Silk gland, treated
-Silk gland, recovery $\square$-Mid gut, treated $\square$-Mid gut, recovery

Fig. 9. The relative levels of expression of Hsp90 in different tissue/breed/treated or recovery combinations. This experiment was performed in triplicate and the quantity of $H s p 90$ mRNA normalized by using the transcript quantity of $\beta$-actin in non-heat shocked tissue at 0 -hour.

greater than that recorded for CSR2. Though, SK4C is not a native of the tropics it is more tolerant of heat stress than other bivoltine breeds and was produced by using "Cambodge" (multivoltine) as one of the parents and screening every generation for individuals that survived better at high temperatures and humidity (Moorthy et al., 2007). Therefore, it is possible that SK4C inherited its tolerance of high temperatures from its multivoltine parent. Earlier studies indicate that bivoltine breeds like KA and their hybrids are to some extent tolerant of $38^{\circ} \mathrm{C}$ (Pillai \& Krishna Swami, 1987). Kumar et al. (2003) studied the effect of high temperature on the quantitative traits of bivoltine breeds and reports 3 line produced oval cocoons and 3 produced dumbbell cocoons that are more tolerant and also studied the tolerance of their hybrids and double hybrids.

Tolerance of B. mori of high temperatures is influenced by both environmental and genetic factors (Kumar et al., 2012). The better survival of a silkworm strain in the field is governed by molecular mechanisms in their cells. Investigating the production of heat shock proteins by silkworms in response to a heat shock might provide an insight into the cytoprotective aspect of their tolerance of thermal stress. The information obtained is also likely to provide a clue to the performance of a breed in the field and assist in the breeding of more heat-tolerant breeds. Therefore, the expression of $9 \mathrm{Hsp}$ genes in the fat body, mid gut and silk gland tissues of Nistari, CSR2 and SK4C in response 
TABLE 3. Two-way ANOVA on each $H s p$ gene expression in silkworm larvae using breed and tissue as factors.

\begin{tabular}{|c|c|c|c|c|}
\hline Source & $D F$ & Mean Square & $F$ & $P$ value \\
\hline \multicolumn{5}{|l|}{ Hsp90 } \\
\hline Breed & 2 & 108.2 & 25.5 & $0.0001^{* *}$ \\
\hline Tissue & 2 & 255 & 60.1 & $0.0001^{* *}$ \\
\hline Breed $*$ Tissue & 4 & 10 & 2.3 & $0.067^{\mathrm{NS}}$ \\
\hline Error & 45 & 4.2 & & \\
\hline \multicolumn{5}{|l|}{ Hsp70 } \\
\hline Breed & 2 & 291985.3 & 26.8 & $0.0001^{* *}$ \\
\hline Tissue & 2 & 474519 & 43.6 & $0.0001^{* *}$ \\
\hline Breed $*$ Tissue & 4 & 39708.3 & 3.64 & $0.012^{*}$ \\
\hline Error & 45 & 10884.6 & & \\
\hline \multicolumn{5}{|l|}{ Hsp40 } \\
\hline Breed & 2 & 77942.3 & 34.2 & $0.0001^{* *}$ \\
\hline Tissue & 2 & 142355.3 & 62.5 & $0.0001^{* *}$ \\
\hline Breed $*$ Tissue & 4 & 8737.7 & 3.84 & $0.009^{* *}$ \\
\hline Error & 45 & 2277.7 & & \\
\hline \multicolumn{5}{|l|}{ Hsp23.7 } \\
\hline Breed & 2 & 23522 & 97.2 & $0.0001^{* *}$ \\
\hline Tissue & 2 & 78123.9 & 322.9 & $0.0001^{* *}$ \\
\hline Breed $*$ Tissue & 4 & 9284.1 & 38.3 & $0.0001^{* *}$ \\
\hline Error & 45 & 241.9 & & \\
\hline \multicolumn{5}{|l|}{ Hsp21.4 } \\
\hline Breed & 2 & 1.679 & 16.2 & $0.0001^{* *}$ \\
\hline Tissue & 2 & 14.55 & 140.6 & $0.0001^{* *}$ \\
\hline Breed $*$ Tissue & 4 & 0.508 & 4.91 & $0.002^{* *}$ \\
\hline Error & 45 & 0.103 & & \\
\hline \multicolumn{5}{|l|}{ Hsp20.8 } \\
\hline Breed & 2 & 39401.4 & 25.1 & $0.0001^{* *}$ \\
\hline Tissue & 2 & 109159.5 & 69.5 & $0.0001^{* *}$ \\
\hline Breed $*$ Tissue & 4 & 6214.3 & 3.95 & $0.008^{* *}$ \\
\hline Error & 45 & 1571.9 & & \\
\hline \multicolumn{5}{|l|}{ Hsp20.4 } \\
\hline Breed & 2 & 7483063.5 & 16.02 & $0.0001^{* *}$ \\
\hline Tissue & 2 & 11383226.8 & 24.4 & $0.0001^{* *}$ \\
\hline Breed $*$ Tissue & 4 & 3145581.4 & 6.73 & $0.0001^{* *}$ \\
\hline Error & 45 & 466933.9 & & \\
\hline \multicolumn{5}{|l|}{ Hsp20.1 } \\
\hline Breed & 2 & 1108.845 & 136.8 & $0.0001^{* *}$ \\
\hline Tissue & 2 & 1175.669 & 145.1 & $0.0001^{* *}$ \\
\hline Breed $*$ Tissue & 4 & 739.429 & 91.2 & $0.0001^{* *}$ \\
\hline Error & 45 & 8.106 & & \\
\hline \multicolumn{5}{|l|}{ Hsp19.9 } \\
\hline Breed & 2 & 4854.991 & 37.7 & $0.0001^{* *}$ \\
\hline Tissue & 2 & 23796.682 & 184.6 & $0.0001^{* *}$ \\
\hline Breed $*$ Tissue & 4 & 2921.418 & 22.7 & $0.0001^{* *}$ \\
\hline Error & 45 & 128.885 & & \\
\hline
\end{tabular}

${ }^{\mathrm{NS}}$ no significant difference; ${ }^{*}$ significant; ${ }^{* *}$ highly significant.

to a heat shock of $1 \mathrm{~h}$ at $36^{\circ} \mathrm{C}$ and after being allowed to recover for $2 \mathrm{~h}$ at $25 \pm 2^{\circ} \mathrm{C}$ was determined. The expression of Hsp genes was up-regulated in all the tissues of the silkworm breeds tested after heat shock, which indicates their products are possibly used to protect silkworms against heat shock. Two-way ANOVA of the results revealed significant differences $(P<0.05)$ in the levels of expression of most of the Hsp genes (except Hsp90) at the tissue level and among breeds. Irrespective of the level of thermotolerance of the different breeds, the level of expression of Hsp genes was more pronounced in fat body than other tissues. This may be due to the anatomical position of the fat body, which is located beneath the cuticle whereas the mid gut and silk gland are surrounded by fat body. Hence any thermal stress first affects the fat body and then other tissues (Kajiwara et al., 2006). Moreover, the fat body in insects is described as the invertebrate liver, which functions as a storage tissue and site of synthesis of numerous biological substances required for the proper physiological functioning of silkworms. Further, these results indicate the sensitivity of different tissues to heat stress. Similar observations on the variation of Hsp expression in tissues are recorded for B. mori (Velu et al., 2008) and other insects like Heliothis armigera (Singh \& Lakhotia, 2000).

In the susceptible (CSR2), tolerant (Nistari) and moderately tolerant (SK4C) the transcription of the Hsp gene increased most in Nistari, less so in SK4C and least in CSR2. That is greater levels of Hsp synthesis were recorded under heat shock in the tolerant than in the susceptible breed. In order to study the correlation between transcriptional and translational products of Hsps in B. mori, Li et al. (2012) exposed 4 day old $5^{\text {th }}$ instar larvae of thermotolerant $(\mathrm{Ni}$ stari) and thermo sensitive (Jingsong) to a heat shock of $45^{\circ} \mathrm{C}$ for $35 \mathrm{~min}$ and $41^{\circ} \mathrm{C}$ for $60 \mathrm{~min}$ and after recovering for 2 and $4 \mathrm{~h}$ the level of expression of Hsps were measured. This revealed a higher expression of Hsp 19.9, Hsp20.4 and $H s p 70$ in the thermo sensitive breed than in the tolerant breed. As in Locusta migratoria (Wang \& Kang, 2005), the phenotypic variation in the thermotolerance of silkworm is also heritable (Kato et al., 1989) and hence controlled by genetic factors. Further, Li et al. (2012) show that thermotolerance varies with breed, sex, treatment and recovery period in silkworm. Similarly, Heredia-Middleton et al. (2008) report different thermal profiles in the expression of $H s p 70$ in three different clonal lines of rainbow trout.

Compared to CSR2 the levels of expression of $s H s p$ were more pronounced in Nistari with a 10.3 times increase in sHsp20.4, 9.7 times increase in sHsp20.1 and a 1.3 times increase in $s H s p 21.4$. Other than $s H s p$, the expression of $H s p 70$ was 2.3 times higher in the tolerant than the susceptible breed. Previous reports indicate that the increase in mRNA level of Hsp70 after heat shock of 1.5 to 4 -fold is significant (Snutch et al., 1988; Requena et al., 1992; Qin et al., 2003), even though it can vary from 1 - to 1000-fold (Lindquist, 1986). Hence, Hsp70 has a prominent role in heat tolerance; it is a major molecular chaperon involved in protecting organisms from extreme temperatures, by chaperoning unfolded proteins (Parsell \& Lindquist, 1993). Besides its protein protecting role under stress, high levels of Hsp 70 are known to protect intact larvae from thermal inactivation by alcohol dehydrogenase and thermal inhibition of feeding (Feder \& Krebs, 1998). Small heat shock proteins ( $\mathrm{sH}$ sps) bind partially denatured proteins, thereby preventing irreversible protein aggregation during stress (Sun \& Mac Rae, 2005). Small Hsps functions by transferring bound proteins to ATP dependent chaperones, such 
as $H s p 70$, and refolding (Richter et al., 2010). Small Hsps form oligomeric complexes during heat shock and the disaggregation of protein complexes is a prerequisite for efficient chaperone function (Haslbeck et al., 1999).

Keshan et al. (2014) report that the up-regulation of Hsp90 gene is associated with the ability of silkworms to survive mild and mild-to-severe heat stress during the pupal stage. In Drosophila cells Hsp70 appears to be the primary protein involved in thermotolerance (Parsell et al., 1993). Carmel et al. (2011) report a high positive correlation between the levels of Hsp40 expression and induced thermotolerance in fruit flies, which implies a significant contribution of the Hsp40 gene to thermoadaptation. Coulon-Bublex \& Mathelin (1991) report the appearance of a $70 \mathrm{kDa}$ stress response protein after heat shock in the diapausing embryos of B. mori. Howrelia et al. (2011) suggest that thermotolerance can be achieved by the induction of Hsp72 in the larval haemolymph by subjecting the $B$. mori cross-breed PM $\times \mathrm{CSR} 2$ to several heat shock treatments. Sakano et al. (2006) report an increase in the mRNA transcripts levels of sHsps (sHsp19.9, sHsp20.1, sHsp20.4, sHsp20.8 and sHsp23.7) in fat body of B. mori after heat shocks of different durations. But the amount of sHsp21.4 mRNA is decreased by increasing in the duration of the heat shock. In our experiment expression of $s H s p 21.4$ was also low. The splicing process is inhibited by a heat shock and hence for the maximal synthesis during thermal stress, the Hsp genes lack introns (Yost \& Lindquist, 1986). The $s H s p 21.4$ gene is speculated to have one intron and hence a low expression. Li et al. (2012) record the up-regulation of sHsps, including Hsp20.4 and Hsp20.8 in the posterior silk gland of silkworms at high temperatures. BmHsp27.4, a novel gene in $B$. mori, has an important role in its response to high-temperature stress (Wang et al., 2014). Li et al. (2014) report higher mRNA levels of Hsp19.9, Hsp23.7, $H s p 40$ and Hsp 90 after a $24 \mathrm{~h}$ continuous heat shock in a tolerant variety (bivoltine) of silkworm than in a susceptible variety (bivoltine). Further Li et al. (2014) suggest that these Hsps and their levels of expression may play important roles in providing resistance to high temperature stress in different varieties of silkworm. The expression of different Hsps differs within and between tissues. Therefore, in this study the expression of nine Hsp genes was analyzed in three tissues of three breeds that differed in their thermotolerance. The expressions of all nine Hsp genes were upregulated in all the tissues tested. The levels of expression of the nine Hsp genes were correlated with the thermotolerance of the silkworm breeds studied. Thus the levels of expression of all the nine $H s p$ genes collectively facilitate the survival of silkworm larvae at high temperatures.

Molecular mechanisms underlying the up-regulation of heat shock proteins are different in Nistari and CSR2 because they have completely different genetic backgrounds and natural thermal regimes. Similarly, Garbuz et al. (2008) show that although a 30-min heat shock treatment increases Hsp 70 synthesis two to three fold in Stratiomys japonica (naturally thermo-tolerant species), it resulted in the production of significantly less Hsp70 in Oxycera pardalina, a cold environment species belonging to the same family (Stratiomyidae, Diptera). But in case of SK4C, it was produced by crossing female SK4 with male Cambodge and the $\mathrm{F}_{1}$ males were then backcrossed with the females of cyclical backcross parent, $\mathrm{SK} 4$, to produce $\mathrm{BC}_{1}$, the males of which were backcrossed with SK4. This backcrossing was repeated for six generations, followed by two generations of self-crossing. Larvae of each generation were screened at $33^{\circ} \mathrm{C}$ (Moorthy et al., 2007b). The genetic differences between the parents are believed to be responsible for the thermotolerance of SK4C. After a heat shock at $36^{\circ} \mathrm{C}$ for 1 $\mathrm{h}$ the level of expression of Hsps in SK4C was lower than in Nistari and higher than in CSR2. Similar results are also reported by Lin et al. (2014) for a near isogenic line. Further, Lin et al. suggest that there are many quantitative trait loci for thermotolerance on several chromosomes of silkworms as in D. melanogaster (Morgan \& Mackay, 2006). It is likely that SK4C did not inherit all of the quantitative trait loci for thermotolerance of Cambodge. Therefore, the intermediate expression of Hsps in SK4C is due to a partial inheritance of the quantitative trait loci for thermotolerance of Cambodge. In order to survive at the high temperatures used for screening SK4C has to use the quantitative trait loci for thermotolerance it inherited from Cambodge. Therefore, of the bivoltine breeds, SK4C had best percentage survival and its level of expression of Hsps was almost twice that recorded for CSR2 larvae. In particular, the level of expression of $H s p 70$ was 1.5 times higher in SK4C than CSR2 larvae. Of the $s H s p$, the levels of expression of sHsp20.4 and sHsp20.1 were 3.5 and 2.3 times higher in SK4C than CSR2. The higher level of expression of Hsp enhances the thermotolerance of SK4C by protecting the organism from protein injury due to thermal stress.

As the thermotolerance of the different breeds differ there is scope for breeders' to select for silkworm breeds that are more tolerant of heat stress. Earlier attempts to identify a bivoltine breed with high thermotolerance that could be used as a parent for breeding for high temperature tolerance were based solely on percentage pupation at a high temperature (Kumar et al., 2002, 2003, 2004; Krishna Rao et al., 2003). This study indicates that SK4C was able to survive high temperatures by using the quantitative trait loci for thermotolerance it inherited from its thermotolerant parent. That the percentage survival at a high temperature of SK4C was the highest of the bivoltine breeds and its levels expression of nine Hsp genes were higher than that recorded for CSR2 support this. The level of expression of $H s p$ genes in the fat body, mid gut and silk gland after a heat shock is the way silkworms respond to a heat shock and survive the fluctuating environmental conditions it experiences in the field (Chavadi et al., 2006). Therefore, SK4C with it high level of expression of Hsp genes (compared to CSR2) is better able to survive high temperature conditions than other bivoltine breeds. In addition, the DNA profile of SK4C, with 5 microsatellite markers associated with thermotolerance, is exactly the same as that of thermotolerant silkworm breeds (Moorthy et al., 2013). Indian sericulture is largely dependent on cross breeds produced 
by using multivoltine breeds as the thermotolerant parent, which yield poor quality silk. Therefore, by producing bivoltine $\times$ bivoltine hybrids using SK4C as the thermotolerant parent, the hybrid will be bivoltine and will produce high quality silk. Since, breeding continuously aims to produce new breeds with the desired traits, silkworm breeders' aiming to produce a new bivoltine breed tolerant of high temperatures can use SK4C as the thermotolerant bivoltine parent and so amalgamate its thermotolerance with other economically important traits.

In conclusion, the thermotolerance and expression of $H s p$ genes varied in different silkworm breeds. Their thermotolerant ability was associated with the level of expression of Hsp genes. These findings provided a better understanding of the relationship between $H s p$ expression and thermotolerance in silkworms. In addition, the results indicate that it is the sHsp (except $s H s p 21.4$ ) and Hsp 70 genes that are mainly involved in the tolerance of thermal stress by working as molecular chaperons to protect silkworms from heat shock. The SK4C breed with the highest percentage pupation at high temperatures (among bivoltines) and a high level of expression of Hsp genes after heat shock survives better than other bivoltine breeds at high temperatures. Therefore, it can be utilized as a parent for breeding new bivoltine breeds/hybrids that are tolerant of high temperature conditions.

\section{REFERENCES}

Benchamin K.V. \& Jolly M.S. 1986: Principles of silkworm rearing. In Mahalingam S. (ed.): Proceedings of the Seminar on Problems and Prospects of Sericulture. Vellore, India, pp. 63-108.

Boutet I., Tanguy A., Rousseau S., Auffet M. \& Moraga D. 2003: Molecular identification and expression of heat shock cognate $70(h s c 70)$ and heat protein $70(h s p 70)$ genes in the Pacific oyster Crassostrea gigas. — Cell Stress Chaper. 8: 76-85.

Brugge J.S., Erikson E. \& Erikson R.L. 1981: The specific interaction of the Rous sarcoma virus transforming protein, pp60src, with two cellular proteins. - Cell 25: 363-372.

Carmel J., Rashkovetsky E., Nevo E. \& Korol A. 2011: Differential expression of small heat shock protein genes Hsp23 and Hsp40, and heat shock gene Hsr-omega in fruit flies (Drosophila melanogaster) along a microclimatic gradient. $-J$. Hered. 102: 593-603.

Coulon-Bublex M. \& Mathelin J. 1991: Variations in the rate of synthesis of heat shock proteins HSP70, between laying and neurula, the diapausing embryo of the silkworm Bombyx mori. - Sericologia 31: 295-300.

FEDER M.E. 1996: Ecological and evolutionary physiology of stress proteins and the stress response: the Drosophila melanogaster model. In Johnston I.A. \& Bennett A.F. (eds): Animals and Temperature: Phenotypic and Evolutionary Adaptation to Temperature. Cambridge University Press, Cambridge, pp. 79-102.

Feder M.E. \& Hofmann G.E. 1999: Heat-shock proteins, molecular chaperones, and the stress response, evolutionary and ecological physiology. - Annu. Rev. Physiol. 61: 243-282.

Feder M.E. \& Krebs R.A. 1998: Natural and genetic engineering of the heat-shock protein hsp70 in Drosophila melanogaster: consequences for thermotolerance. - Am. Zool. 38: 503-517.

FInK A.L. 1999: Chaperone-mediated folding. - Physiol. Rev. 79: 425-449.
Garbuz D.G., Zatsepina O.G., Przhiboro A.A., Yushenova I., Guzhova I.V. \& Evgen'ev M.B. 2008: Larvae of related Diptera species from thermally contrasting habitats exhibit continuous up-regulation of heat shock proteins and high thermotolerance. - Mol. Ecol. 17: 4763-4777.

Gehring W.J. \& WehNER R. 1995: Heat shock protein synthesis and thermotolerance in Cataglyphis, an ant from the Sahara desert. — Proc. Natn. Acd. Sci. U.S.A. 92: 2994-2998.

Harjeet Singh \& Suresh Kumar N. 2010: On the breeding of bivoltine breeds of the silkworm, Bombyx mori L. (Lepidoptera: Bombycidae), tolerant to high temperature and high humidity conditions of the tropics. - Psyche, Article ID 892452, 15 pp. doi:10.1155/2010/892452.

Haslbeck M., Walke S., Stomer T., Ehrnsperger M., White H.E., Chen S., Saibil H.R. \& Buchner J. 1999: Hsp 26: A temperature-regulated chaperone. - EMBO J. 18: 6744-6751.

HE Y. \& OshiKI T. 1984: Study on cross breeding of a robust silkworm race for summer and autumn rearing at low latitude area in China. - J. Sericult. Sci. Jpn. 53: 320-324.

Heredia-Middleton P., Brunelli J., Drew R.E. \& Thorgaard G.H. 2008: Heat shock protein (HSP70) RNA expression differs among rainbow trout (Oncorhynchus mykiss) clonal lines. - Comp. Biochem. Physiol. (B) 149: 552-556.

Howrelia J.H., Patnaik B.B., Selvanayagam M. \& Rajakumar S. 2011: Impact of temperature on heat shock protein expression of Bombyx mori cross-breed and effect on commercial traits. J. Environ. Biol. 32: 99-103.

Hsien F.K., Yu S.J., Su S.Y. \& Peng S.J. 1995: Studies on the thermotolerance of the silkworm, Bombyx mori. - Chin. J. Entomol. 15: 91-101.

Huang P.J., Chen J.H., Hong D.H. \& Chen C.N. 1979: Preliminary study on the inheritance of tolerance to high temperature in some silkworm strains. - J. Agric. Assoc. China 105: 2339.

Joy O. \& Gopinathan K.P. 1995: Heat shock response in mulberry silkworm races with different thermotolerances. $-J$. Biosci. 20: 499-513.

Kajiwara H., Itou Y., Imamaki A., Nakamura M., Mita K. \& IshiZAKA M. 2006: Proteomic analysis of silkworm fat body. $-J$. Insect. Biotechnol. Sericol. 75: 47-56.

Kappé G., Franck E., Verschuure P., Boelens W.C., Leunissen J.A. \& DE JonG W.W. 2003: The human genome encodes 10 alpha-crystallin-related small heat shock proteins: HspB1-10. - Cell Stress Chaper. 8: 53-61.

Kato M., Nagayasu K., Ninagi O., Hara W. \& Watanabe A. 1989: Studies on resistance of the silkworm, Bombyx mori L. for high temperature. In: Proceedings of the 6th International Congress of SABRAO (II). India, pp. 953-956.

Keshan B., Paul S., Bembem T. \& Devi K.S. 2014: Tissue-specific expression patterns of heat shock protein 90 transcripts in silkworm, Bombyx mori. - J. Entomol. Zool. Stud. 2(6): 53-59.

Kıм K.K., Kıм R. \& Kıм S.H. 1998: Crystal structure of a small heat-shock protein. - Nature 394: 595-599.

Koundinya P.R., Kumaresan P., Sinha R.K. \& Thangavelu K. 2003: Screening of promising germplasm of polyvoltine silkworm (Bombyx mori L.) for thermotolerance. - Indian J. Sericult. 42: 67-70.

Krishna Rao S., Govindaraju S.T., Mahadevappa R., RaghuraMAN \& Bongale U.D. 2003: Evolution of new productive bivoltine races for tropical conditions (Abstract). In: National Conference on Tropical Sericulture for Global Competitiveness, 5-7 November, Central Sericultural Research Training Institute, Mysore, India, p. 19. 
KrishnaSWAmI S. 1978: New Technology of Silkworm Rearing Bulletin. No. 2. Central Sericultural Reasearch Training Institute, Mysore, $23 \mathrm{pp}$.

Lakshmi H., Chandrashekharaiah, Ramesh Babu M., Raju P.J., SAHA A.K. \& BAJPAI A.K. 2011: HTO5 $\times$ HTP5, the new bivoltine silkworm (Bombyx mori L.) hybrid with thermo-tolerance for tropical areas. - Int. J. Plant Anim. Environ. Sci. 1: 88-104.

Landais I., Pommeta J.M., Mitab K., Nohatab J., Gimeneza S., Fourniera P., Devauchellea G., Duonor-Ceruttia M. \& OgliASTROA M. 2001: Characterization of the cDNA encoding the $90 \mathrm{kDa}$ heat-shock protein in the Lepidoptera Bombyx mori and Spodoptera frugiperda. - Gene 271: 223-231.

Lee G.J., Pokala N. \& Vierling E. 1995: Structure and in vitro molecular chaperone activity of cytosolic small heat shock proteins from pea. - J. Biol. Chem. 270: 10432-10438.

Li B., XIa Q.Y., FujiI H., Banno Y. \& Lu C. 2005: Expression of the small heat-shock protein Bmhsp19.9 gene in silkworm (Bombyx mori). - Chin. J. Agr. Biotechnol. 13: 195-201.

Li J., Moghaddam S.H.H., Du X., Zhong B.X. \& Chen Y.Y. 2012: Comparative analysis on the expression of inducible HSPs in the silkworm, Bombyx mori. - Mol. Biol. Rep. 39: 3915-3923.

Li Q.R., XIAO Y., Wu F.Q., Ye M.Q., Luo G.Q., XING D.X., Li L. \& YANG Q. 2014: Analysis of midgut gene expression profiles from different silkworm varieties after exposure to high temperature. - Gene 549: 85-96.

Lin H.J., Li Z., Dang X.Q., Su W.J., Zhou Z.Y. \& Wang L.L. 2014: Short-term increased expression of the heat shock protein 70 family members during heat shock is positively correlated with basal thermotolerance in the midgut of three strains of the silkworm, Bombyx mori. - Afr. Entomol. 22: 24-29.

LINDQUisT S. 1986: The heat-shock response. - Annu. Rev. Biochem. 55: 1151-1191.

Lindquist S. \& Craig E.A. 1988: The heat-shock proteins. Annu. Rev. Genet. 22: 631-677.

LOHMANN C.M.F. \& RidDiford L.M. 1992: The heat-shock response and heat sensitivity of Bombyx mori. - Sericologia 32: 533-537.

Lozovskaya E.R. \& Evgen'ev M.B. 1984: Heat shock in and regulation of genome activity. - Mol. Biol. 20: 142-185.

Margulis B.A. \& Guzhova I.V. 2000: Stress proteins in eukaryotic cell. - Tsitologiya 42: 323-342 [in Russian, English abstr.].

Moghaddam S.H.H., Du X., Li J., CaO J.R., Zhong B.X. \& CheN Y.Y. 2008: Proteome analysis on differentially expressed proteins of the fat body of two silkworm breeds, Bombyx mori, exposed to heat shock exposure. - Biotechnol. Bioproc. Engin. 13: 624-631.

Moorthy S.M., Chandrakanth N., Ashwath S.K., Nirmal Kumar S., Naseema Begum A. \& QAdRI S.M.H. 2013: Identification of molecular markers (SSR) associated with thermotolerance in silkworm Bombyx mori. In: 6th BACSA International Conference "Building Value Chains in Sericulture" "BISERICA”, Padua, Italy, 7-12 April 2013. BISERICA, Council of Research and Experiments in Agriculture, Apiculture and Sericulture, Padua, pp. 253-254.

Moorthy S.M., Das S.K., Rao P.R.T., Raje Urs S. \& Sarkar A. 2007a: Evaluation and selection of potential parents based on selection indices and isozyme variability in silkworm, Bombyx mori L. - Int. J. Indust. Entomol. 14: 1-7.

Moorthy S.M., Das S.K., Kar N.B., Mandal K. \& BaJPai A.K. 2007b: Breeding of bivoltine silkworm breeds suitable for tropics and identification of multi $\times$ bi silkworm hybrid for locommercial exploitation in Eastern India. - Perspectives Cytol. Genet. 13: 215-227.
Morgan T.J. \& Mackay T.F. 2006: Quantitative trait loci for thermotolerance phenotypes in Drosophila melanogaster. - Heredity 96: 232-242.

MоRiмото R.I. 1998: Regulation of transcriptional response: cross talk between a family of heat shock factors, molecular chaperones, and negative regulators. - Genes Dev. 12: 37883796.

Morimoto R.J., Jolly C., Satyal S., Mathew A., Shi Y. \& KitaGAWA K. 1999: Molecular chaperones and the heat shock response. - Br. J. Cancer 80: S19.

Murakami A. \& Ohtsuki Y. 1989: Genetic studies on tropical races silkworm (Bombyx mori) with special reference to cross breeding strategy between tropical and temperate races. I. Genetic nature of the tropical multivoltine strain Cambodge. Jap. Agric. Res. Quart. 23: 37-45.

Naкамото H. \& Vigh L. 2007: The small heat shock proteins and their clients. - Cell. Mol. Life Sci. 64: 294-306.

Nover L. \& SCharf K.D. 1997: Heat stress proteins and transcription factors. - Cell. Mol. Life Sci. 53: 80-103.

Pandey P., Saleh A., Nakazawa A., Kumar S., Srinivasula S.M., Kumar V., Weichselbaum R., Nalin C., Alnemri E.S., Kufe D. $\&$ Kharbanda S. 2000: Negative regulation of cytochrome Cmediated oligomerization of Apaf-1 and activation of procaspase-9 by heat shock protein 90. - EMBO J. 19: 4310-4322.

Parsell D.A. \& Lindquist S. 1993: The function of heat-shock proteins in stress tolerance: degradation and reactivation of damaged proteins. - Annu. Rev. Genet. 27: 437-496.

Parsell D.A., Taulien J. \& Lindquist S. 1993: The role of heatshock proteins in thermotolerance. - Philos. Trans. R. Soc. Lond. (B) 339: 279-285.

Pillai V.S. \& Krishnaswami S. 1987: Adoptability of silkworm Bombyx mori (L.) to tropical conditions: III. Studies on the effect of high tempetature during later development stages of silkworm. - Ind. J. Sericult. 26: 63-71.

Pratt W.B. \& Toft D.O. 2003: Regulation of signaling protein function and trafficking by the hsp90/hsp70-based chaperone machinery. - Exp. Biol. Med. 228: 111-133.

Qin W., Tyshenko M.G., Wu B.S., Walker V.K. \& Robertson R.M. 2003: Cloning and characterization of a member of the hsp 70 gene family from Locusta migratoria, a highly thermotolerant insect. - Cell Stress Chaper. 8: 144-152.

Requena J.M., Jimenez-Ruiz A. \& Soto M. 1992: Regulation of hsp70 expression in Trypanosoma cruzi by temperate and growth phase. - Mol. Biochem. Parasitol. 53: 201-211.

Richter K., Haslbeck M. \& Buchner J. 2010: The heat shock response: life on the verge of death. - Mol. Cell 40: 253-266.

SaKano D., Li B., Xia Q.Y., Yамамото K., Funi H. \& Aso Y. 2006: Genes encoding small heat shock proteins of the silkworm, Bombyx mori. - Biosci. Biotechnol. Biochem. 70: 2443-2450.

SHIROTA T. 1992: Selection of healthy silkworm strain through high temperature rearing of fifth instar larvae. - Rep. Silk Sci. Res. Inst. 40: 33-40.

SingH H. \& KUMAR N.S. 2010: On the breeding of bivoltine breeds of the silkworm, Bombyx mori L. (Lepidoptera: Bombycidae), tolerant to high temperature and high humidity conditions of the tropics. - Psyche, Article ID 892452, 15 pp.

Singh A.K. \& Lakhotia S.C. 2000: Tissue-specific variations in the induction of Hsp70 and Hsp64 by heat shock in insects. Cell Stress Chaper. 5: 90-97.

Snutch T.P., Heschl M.F.P. \& Baillie D.L. 1988: The Caenorhabditis elegans hsp70 gene family: a molecular genetic characterization. - Gene 64: 241-255.

Sreekumar S., Ashwath S.K., Slathia M., Kumar S.N. \& Qadri S.M.H. 2011: Detection of a single nucleotide polymorphism 
(SNP) DNA marker linked to cocoon traits in the mulberry silkworm, Bombyx mori (Lepidoptera: Bombycidae). — Eur. J. Entomol. 108: 347-354.

Srivastava P.P., Kar P.K., Awasthi A.K. \& Raje Urs S. 2007: Identification and association of ISSR markers for thermal stress in polyvoltine silkworm Bombyx mori. - Russ. J. Genet. 43: 858-864.

Sudhakara Rao P., Narasimha Nayaka A.R., Mamatha M., SowMYASHREE T.S., BASHIR I. \& ILAHI I. 2007: Development of new robust bivoltine hybrid SR2 $\times$ SR5 for rearing throughout the year. - Int. J. Indust. Entomol. 14: 93-97.

Sun Y. \& MAC RAE T.H. 2005: Small heat shock proteins: molecular structure and chaperone function. - Cell. Mol. Life Sci. 62 $2460-2476$

Suresh Kumar N., Yamamoto T., Basavaraja H.K. \& Datta R.K. 2001: Studies on the effect of high temperature on $F_{1}$ hybrids between polyvoltine and bivoltine silkworm races of Bombyx mori L. - Int. J. Indust. Entomol. 2: 123-127.

Suresh Kumar N., Basavaraja H.K., Kishor Kumar C.M., Mal REDDY N. \& DATTA R.K. 2002: On the breeding of CSR18 $\times$ CSR19 a robust hybrid of silkworm, Bombyx mori L. for tropics. - Int. J. Indust. Entomol. 5: 153-162.

Suresh Kumar N., Basavaraja H.K., Mal Reddy N. \& Dandin S.B. 2003: Effect of high temperature and high humidity on the quantitative traits of parents, foundation crosses, single and double hybrids of bivoltine silkworm, Bombyx mori L. - Int. J. Indust. Entomol. 6: 197-202.

Suresh Kumar N., Basavaraja H.K. \& Dandin S.B. 2004: Breeding of robust bivoltine silkworm, Bombyx mori L. for temperature tolerance - a review. - Indian J. Sericult. 43: 111-124.

Suresh Kumar N., Basavaraja H.K., Joge P.G., Mal Reddy N., Kalpana G.V. \& Dandin S.B. 2006: Development of new robust bivoltine hybrid (CSR46 $\times$ CSR47) of Bombyx mori L. for tropics. - Indian J. Sericult. 45: 21-29.

Suresh Kumar N., Singh H., Saha A.K. \& Bindroo B.B. 2011: Development of bivoltine double hybrid of the silkworm, Bombyx mori L. tolerant to high temperature and high humidity conditions of the tropics. - Univ. J. Environ. Technol. 1: 423-434.
Suresh Kumar N., Lakshmi H., Saha A.K., Bindroo B.B. \& LONGKUMER N. 2012: Evaluation of bivoltine silkworm breeds of Bombyx mori L. under West Bengal conditions. - Univ. J. Environ. Res. Technol. 2: 393-401.

Ul'Masov K.A., Shammakov S., Karaev K.K. \& Evegen'ev M.B. 1992: Heat shock proteins and thermoresistance in lizards. - Proc. Natn. Acad. Sci. U.S.A. 89: 1666-1670.

Van Montfort R.L.M., Slingsby C. \& Vierling E. 2001: Structure and function of the small heat shock protein/alpha-crystallin family of molecular chaperones. - Adv. Protein Chem. 59: 105-156.

Vasudha B.C., Aparna H.S. \& Manjunatha H.B. 2006: Impact of heat shock on heat shock proteins expression, biological and commercial traits of Bombyx mori. - Insect Sci. 13: 243-250.

Velu D., Ponnuvel K.M. \& QADRI S.M.H. 2008: Expression of the heat shock protein genes in response to thermal stress in the silkworm, Bombyx mori. - Int. J. Indust. Entomol. 16: 21-27.

WANG X.H. \& KANG L. 2005: Differences in egg thermotolerance between tropical and temperate populations of the migratory locust Locusta migratoria (Orthoptera: Acridiidae). - J. Insect Physiol. 51: 1277-1285.

Wang H., Fang Y., Bao Z., Jin X., Zhu W., Wang L., LiU T., Ji H., WANG H., XU S. \& Sima Y. 2014: Identification of a Bombyx mori gene encoding small heat shock protein BmHsp27.4 expressed in response to high-temperature stress. - Gene 538: $56-62$.

Welch W.J. \& Feramisco J.R. 1982: Purification of the major mammalian heat shock proteins. - J. Biol. Chem. 257: 1494914959.

Welte M.A., Tetrault J.M., Dellavalle R.P. \& Lindquist S.L. 1993: A new method for manipulating transgenes: engineering heat tolerance in a complex, multicellular organism. - Curr. Biol. 3: 842-853.

Yost H.J. \& LindQuist S. 1986: RNA splicing is interrupted by heat shock protein and is rescued by heat shock protein synthesis. - Cell 45: 185-193.

Received December 10, 2014; revised and accepted July 27, 2015 Prepublished online September 22, 2015 